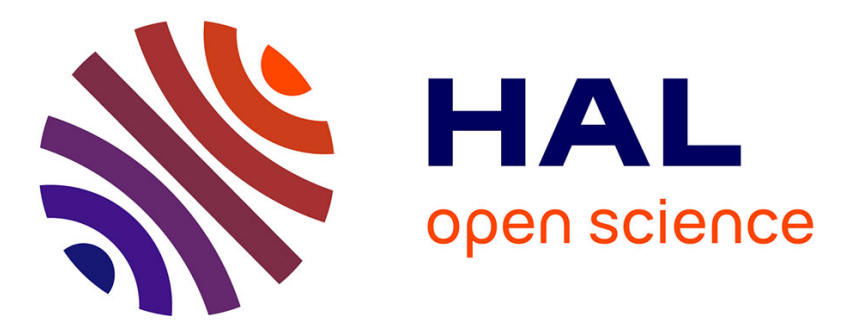

\title{
Bibliography on Induction Motors Faults Detection and Diagnosis
}

\author{
Mohamed Benbouzid
}

\section{To cite this version:}

Mohamed Benbouzid. Bibliography on Induction Motors Faults Detection and Diagnosis. IEEE Transactions on Energy Conversion, 1999, 14 (4), pp.1065-1074. hal-01052297

\section{HAL Id: hal-01052297 \\ https://hal.science/hal-01052297}

Submitted on 25 Jul 2014

HAL is a multi-disciplinary open access archive for the deposit and dissemination of scientific research documents, whether they are published or not. The documents may come from teaching and research institutions in France or abroad, or from public or private research centers.
L'archive ouverte pluridisciplinaire HAL, est destinée au dépôt et à la diffusion de documents scientifiques de niveau recherche, publiés ou non, émanant des établissements d'enseignement et de recherche français ou étrangers, des laboratoires publics ou privés. 


\title{
Bibliography on Induction Motors Faults Detection and Diagnosis
}

\author{
M.E.H. Benbouzid, Member, IEEE \\ University of Picardie "Jules Verne", Amiens, France \\ for the Motor Maintenance and Failure Analysis Working Group, Induction Machinery Subcommittee \\ IEEE Power Engineering Society
}

\begin{abstract}
This paper provides a comprehensive list of books, workshops, conferences, and journal papers related to induction motors faults detection and diagnosis.
\end{abstract}

\section{INTRODUCTION}

I nduction motors are a critical component of many industrial processes and are frequently integrated in commercially available equipment. Safety, reliability, efficiency, and performance are some of the major concerns of induction motor applications. With issues such as aging motors, high reliability requirements, and cost competitiveness, the issues of induction motors faults detection and diagnosis are of increasing importance. For these reasons, during the past twenty years, there has been a continually increasing interest and investigation into induction motors faults detection and diagnosis. As this interest has grown, the literature has also grown. This paper provides then a comprehensive list of books, workshops, conferences, and journal papers related to this important research topic.

The majority of the listed references are directly concerned with induction motors faults detection and diagnosis techniques. However, performing reliable and accurate motor faults detection and diagnosis requires understanding the cause and effect of motor faults to motor performances. It is also important to know how external factors such as loading and temperature can affect the motor faults detection and diagnosis technique and results. Therefore, the proposed bibliography also includes references related to these two last topics.

The references listed below are divided into three groups and listed in reverse chronological order (from the end of the 70 's up to now). The first group contains the information on books [1-5]. The second and third one list workshops, conference [6-222], and journal papers [223-365]. In this last group, we have tried to cover the most relevant journals, mainly the IEEE Transactions and Magazines, the IEE Proceedings and Journals, the European Transactions on Electrical Power, the Electric Machines \& Power Systems Journal, and some reliability and maintenance society journals, such as P/PM Technology, Reliability Engineering, Sound \& Vibration, etc.

\section{REFERENCES}

\section{A. Books}

[1] M.Y. Chow, B. Li and G. Goddu, Intelligent Motor Fault Detection, in Intelligent Techniques in Industry. L.C. Jain, Ed.: CRC Press, 1998.

[2] M.Y. Chow, Methodologies of Using Neural Network and Fuzzy Logic Technologies for Motor Incipient Fault Detection. Singapore: World Scientific Publishing Co. Pte. Ltd., 1997.

[3] M.Y. Chow, Y.S. Lee and H.J. Trussell, Motor Incipient Fault Detection Using Artificial Neural Network and Fuzzy Logic Technologies, in Computer Aided Maintenance, Methodology and Practices. J. Lee, Ed.: Chapman Hall, 1996.

[4] P. Vas, Parameter Estimation, Condition Monitoring, and Diagnosis of Electrical Machines. Oxford: Clarendon Press, 1993.

[5] P.J. Tavner and J. Penman, Condition Monitoring of Electrical Machines. New York: Research Studies Press Ltd., Wiley, 1989.

\section{B. Workshops and Conference Papers}

[6] T.J. Sobczyk et al., "Recognition of rotor eccentricity of induction motors based on the Fourier spectra of phase currents," Proceedings of the 1998 International Conference on Electrical Machines, Istanbul (Turkey), vol. 1, pp. 408-413.

[7] E. Schaeffer et $a l$. , "Unbalanced induction machine simulation dedicated to condition monitoring," Proceedings of the 1998 International Conference on Electrical Machines, Istanbul (Turkey), vol. 1, pp. 414-419

[8] M.F. Cabanas et al., "Experimental application of axial leakage flux to the detection of rotor asymmetries, mechanical anomalies and interturn short circuits in working induction motors," Proceedings of the 1998 International Conference on Electrical Machines, Istanbul (Turkey), vol. 1, pp. 420-425.

[9] G.A. Orcajo et al., "A system for global protection control and diagnosis of industrial plants including electric motors and drives," Proceedings of the 1998 International Conference on Electrical Machines, Istanbul (Turkey), vol. 1, pp. 426-431.

[10] R.S. Wieser et al., "High sensitive rotor cage monitoring during dynamic load operation. The Vienna monitoring method," Proceedings of the 1998 International Conference on Electrical Machines, Istanbul (Turkey), vol. 1, pp. 432-437.

[11] C. Izquierdo et al., "Useful life of HV induction motors in thermal plant," Proceedings of the 1998 International Conference on Electrical Machines, Istanbul (Turkey), vol. 1, pp. 438-442.

[12] A. Ah-Jaco et $a l$., "Modelling of the three phase asynchronous motor. Application to magnetic faults diagnostic," Proceedings of the 1998 International Conference on Electrical Machines, Istanbul (Turkey), vol. 1, pp. 443-447.

[13] F. Filippetti et $a l$., "Current pattern analysis to detect induction machine non rotational anomalies," Proceedings of the 1998 International Conference on Electrical Machines, Istanbul (Turkey), vol. 1, pp. 448-453.

[14] R. Fiser et $a l$., "Modelling of induction motor rotor faults with finite element method," Proceedings of the 1998 International Conference on Electrical Machines, Istanbul (Turkey), vol. 1, pp. 454-459.

[15] G.B. Kliman et al., "Recent developments in on-line motor diagnostics," Proceedings of the 1998 International Conference on Electrical Machines, Istanbul (Turkey), vol. 1, pp. 471-475. 
[16] M.E.H. Benbouzid et al., "Extended Kalman filter-based rotor resistance identification for sensorless induction motors broken bars monitoring," Proceedings of the 1998 International Conference on Electrical Machines, Istanbul (Turkey), vol. 2, pp. 1012-1016.

[17] N. Retière et al., "Experimental investigation of induction machine three phase short-circuits," Proceedings of the 1998 International Conference on Electrical Machines, Istanbul (Turkey), vol. 3, pp. 1522-1527.

[18] S.M.A. Cruz et al., "Rotor cage fault diagnosis in three-phase induction motors, by extended Park's vector approach," Proceedings of the 1998 International Conference on Electrical Machines, Istanbul (Turkey), vol. 3, pp. 1844-1848.

[19] M.E.H. Benbouzid et al., "Induction motor faults detection using advanced spectral analysis technique," Proceedings of the 1998 International Conference on Electrical Machines, Istanbul (Turkey), vol. 3, pp. 1849-1854.

[20] M.E.H. Benbouzid et al., "A decentralized neural network-based architecture for induction motor faults detection," Proceedings of the 1998 International Conference on Electrical Machines, Istanbul (Turkey), vol. 3, pp. 1855-1860.

[21] M.E.H. Benbouzid et al., "Induction motors thermal protection by monitoring winding resistance using the $\mathrm{H}-\mathrm{G}$ diagram," Proceedings of the 1998 International Conference on Electrical Machines, Istanbul (Turkey), vol. 3, pp. 1861-1865.

[22] F.R. Faya et $a l$., "Electromagnetic torque as a new method for on-line induction motor rolling-element bearing damage detection," Proceedings of the 1998 International Conference on Electrical Machines, Istanbul (Turkey), vol. 3, pp. 1866-1871.

[23] R. Ong et al., "Impact of oil lubrication on the magnitude of shaft current in a large oil ring lubricated induction machine," Proceedings of the 1998 International Conference on Electrical Machines, Istanbul (Turkey), vol. 3, pp. 1966-1971.

[24] W.T. Thomson et al., "An appraisal of the mmf-permeance method and finite element models to study static air-gap eccentricity and its diagnosis in induction machines," Proceedings of the 1998 International Conference on Electrical Machines, Istanbul (Turkey), vol. 3, pp. 2182-2187.

[25] R. Fiser et al., "Development of steady-state mathematical model of induction motor with rotor cage faults," Proceedings of the 1998 International Conference on Electrical Machines, Istanbul (Turkey), vol. 3, pp. 2188-2191.

[26] A.H. Bonnett, "Cause, analysis and prevention of motor shaft failures," Proceedings of the 1998 IEEE IAS Pulp and Paper Industry Technical Conference, Portland (USA), pp. 166-180.

[27] M.M. Hodowanec, "Evaluation of anti-friction bearing lubrication methods on motor life cycle cost," Proceedings of the 1998 IEEE IAS Pulp and Paper Industry Technical Conference, Portland (USA), pp. 196-202.

[28] R. Teodorescu et al., "A new parameters identification technique for induction machine diagnosis," Proceedings of the 1998 International Conference on Optimization of Electrical and Electronic Equipments, Brasov (Romania), vol. 2, pp. 567-572.

[29] M.E.H. Benbouzid et al., "Large induction machines faults monitoring by power line signal spectral analysis," Proceedings of the 1998 International Conference on Acoustical and Vibratory Surveillance Methods and Techniques, Senlis (France), Paper E3.

[30] M.E.H. Benbouzid et al., "Induction motors interturn short circuits and bearing wear detection using a decentralized neural networks architecture," Proceedings of the 1998 International Conference on Acoustical and Vibratory Surveillance Methods and Techniques, Senlis (France), Paper P8.

[31] R.S. Wieser et $a l$., "The Vienna induction machine monitoring method. On the impact of the field oriented control structure on real operational behavior of a faulty machine," Proceedings of the 1998 International Conference of the IEEE Industrial Electronics Society, Aachen (Germany), vol. 3, pp. 1544-1549.

[32] N. Arthur et al., "Induction machine condition monitoring with higher order spectra Part I: Fundamentals and fixed frequency operation," Proceedings of the 1998 International Conference of the IEEE Industrial Electronics Society, Aachen (Germany), vol. 3, pp. 1889-1894.
[33] N. Arthur et al., "Induction machine condition monitoring with higher order spectra Part II: Variable frequency operation and automated diagnosis," Proceedings of the 1998 International Conference of the IEEE Industrial Electronics Society, Aachen (Germany), vol. 3, pp. 1895-1900.

[34] S. Shinnaka, "New adaptive vector control for induction motors and its potential application for motor fault detection," Proceedings of the 1998 International Conference of the IEEE Industrial Electronics Society, Aachen (Germany), vol. 4, pp. 1901-1907.

[35] M.E.H. Benbouzid, "A review of induction motors signature analysis as a medium for faults detection," Proceedings of the 1998 International Conference of the IEEE Industrial Electronics Society, Aachen (Germany), vol. 4, pp. 1950-1955.

[36] M.Y. Chow et al., "Set theoretic based neural-fuzzy motor fault detector," Proceedings of the 1998 International Conference of the IEEE Industrial Electronics Society, Aachen (Germany), vol. 4, pp. 1908-1913.

[37] G. Goddu et al., "Motor bearing fault diagnosis by a fundamental frequency amplitude based fuzzy decision system," Proceedings of the 1998 International Conference of the IEEE Industrial Electronics Society, Aachen (Germany), vol. 4, pp. 1961-1965.

[38] F. Filippetti et al., "Recent developments of induction motor drives fault diagnosis using AI techniques," Proceedings of the 1998 International Conference of the IEEE Industrial Electronics Society, Aachen (Germany), vol. 4, pp. 1966-1973.

[39] G. Joksimovic et al., "The detection of interturn short circuits in the stator windings of operating motors," Proceedings of the 1998 International Conference of the IEEE Industrial Electronics Society, Aachen (Germany), vol. 4, pp. 1974-1979.

[40] M.F. Abdel-Magied et al., "Fault detection and diagnosis for rotating machinery: A model-based approach," Proceedings of the 1998 American Control Conference, Philadelphia (USA), vol. 4, pp. 2032-2036

[41] B. Li et al., "Detection of common motor bearing faults using frequency-domain vibration signals and a neural network based approach," Proceedings of the 1998 American Control Conference, Philadelphia (USA), vol. 6, pp. 3291-3296.

[42] C.M. Chen et al., "Electric fault detection for vector-controlled induction motor using the discrete wavelet transform," Proceedings of the 1998 American Control Conference, Philadelphia (USA), vol. 6 , 3297-3301.

[43] M. Vieira et al., "Bayesian analysis for the fault detection of threephase induction machine," Proceedings of the 1998 IEEE International Acoustics, Speech and Signal Processing Conference, Seatle (USA), vol. 4, pp. 2237-2240.

[44] B. Li et al., "Enhancement of the performance of a neural network based motor fault detector using graphical data analysis techniques," Proceedings of the 1998 IEEE World Congress on Computational Intelligence, Anchorage (USA), vol. 1, pp. 63-68.

[45] R. Fiser et al., "Calculation of magnetic field asymmetry of induction motor with rotor faults," Proceedings of the 1998 IEEE Mediterranean Electrotechnical Conference, Tel Aviv (Israel), vol. 2, pp. 1175-1179

[46] R. Fiser et al., "Study of operational behaviour of induction motor with rotor asymmetry," Proceedings of the 1998 IEEE Mediterranean Electrotechnical Conference, Tel Aviv (Israel), vol. 2, pp. 1185-1188.

[47] A. Shirkhodaie et al., "A comparative study on performance of neuralnetworks for condition monitoring of rotary machinery," Proceedings of the 1998 Meeting of the Society for Machinery Failure Prevention Technology, pp. 73-80.

[48] M.A. Cash et al., "Insulation failure prediction in inverter-fed induction machines using line-neutral voltages," Proceedings of the 1998 IEEE Applied Power Electronics Conference, Atlanta (USA), vol. 2, pp. 1035-1039.

[49] N. Arthur et al., "Inverter fed induction machine condition monitoring using the bispectrum," Proceedings of the 1997 IEEE Signal Processing Workshop on Higher-Order Statistics, Banff (Canada), pp. 67-71.

[50] S. Altug et $a l$., "Comparative analysis of fuzzy inference systems implemented on neural structures," Proceedings of the 1997 International Conference on Neural Networks, Houston (USA), vol 1, pp. 426-431. 
[51] A.C. McCormick et al., "Neural networks autoregressive modeling of vibrations for condition monitoring of rotating shafts," Proceedings of the 1997 International Conference on Neural Networks, Houston (USA), vol. 4, pp. 2214-2218.

[52] A. Barbour et al., "Finite element analysis and on-line current monitoring to diagnose airgap eccentricity in three-phase induction motors," Proceedings of the 1997 IEE Electrical Machines and Drives Conference, vol. 1, pp. 150-154.

[53] O.V. Thorsen et al., "Condition monitoring methods, failure identification and analysis for high voltage motors in petrochemical industry," Proceedings of the 1997 IEE Electrical Machines and Drives Conference.

[54] S. Chun et al., "A fuzzy expert system for vibration cause identification in rotating machines," Proceedings of the 1997 IEEE International Conference on Fuzzy Systems, vol. 1, pp. 555-560.

[55] A. Barbour et al., "Finite element study of rotor slot designs with respect to current monitoring for detecting static air-gap eccentricity in squirrel-cage induction motors," Proceedings of the 1997 IEEE IAS Annual Meeting, New Orleans (USA), vol. 1, pp. 112-119.

[56] K.D. Hurst et al., "A thermal monitoring and parameter tuning scheme for induction machines," Proceedings of the 1997 IEEE IAS Annual Meeting, New Orleans (USA), vol. 1, pp. 136-142.

[57] S. Nandi et $a l$., "Performance analysis of a single phase induction motor under eccentric conditions," Proceedings of the 1997 IEEE IAS Annual Meeting, New Orleans (USA), vol. 1, pp. 174-181.

[58] C.M. Riley et al., "A method for sensorless on-line vibration monitoring of induction machines," Proceedings of the 1997 IEEE IAS Annual Meeting, New Orleans (USA), vol. 1, pp. 201-207.

[59] M.A. Cash et al., "Insulation failure prediction in induction machines using line-neutral voltages," Proceedings of the 1997 IEEE IAS Annual Meeting, New Orleans (USA), vol. 1, pp. 208-212.

[60] B. Yazici et al., "An adaptive, on-line, statistical method for bearing fault detection using stator current," Proceedings of the 1997 IEEE IAS Annual Meeting, New Orleans (USA), vol. 1, pp. 213-220.

[61] B. Yazici et al., "An adaptive, on-line, statistical method for detection of broken bars in motors using stator current and torque estimation," Proceedings of the 1997 IEEE IAS Annual Meeting, New Orleans (USA), vol. 1, pp. 221-226.

[62] W.T. Thomson et al., "On-line current monitoring to diagnose airgap eccentricity - An industrial case history of large high-voltage three-phase induction motor," Proceedings of the 1997 IEEE International Electric Machines and Drives Conference, Milwaukee (USA), pp. MA2-4,1-4-3.

[63] A.J.M. Cardoso et al., "Inter-turn stator winding fault diagnosis in three-phase induction motors, Park's vector approach," Proceedings of the 1997 International Electric Machines and Drives Conference Milwaukee (USA), pp. MB1-5.1-5.3.

[64] A.M. Trzynadlowski et al., "Diagnostics of mechanical abnormalities in induction motors using instantaneous electric power," Proceedings of the 1997 IEEE International Electric Machines and Drives Conference, Milwaukee (USA), pp. MB1-9.1-9.3

[65] M.E.H. Benbouzid et al., "Induction motors thermal monitoring by means of rotor resistance identification," Proceedings of the 1997 IEEE International Electric Machines and Drives Conference, Milwaukee, Wisconsin (USA), pp. TD2-4.1-4.3.

[66] J.F. Watson et $a l$., "The use of finite element methods to improve techniques for the early detection of faults in three-phase induction motors," Proceedings of the 1997 IEEE International Electric Machines and Drives Conference, Milwaukee (USA), pp. WB3-9.1-9.3.

[67] R. Fiser et al., "Simulation of steady-state and dynamic performance of induction motor for diagnostic purpose," Proceedings of the 1997 IEEE International Electric Machines and Drives Conference, Milwaukee (USA), pp. WB3-10.1-10.3.

[68] D. Stegemann et al., "Failure cause analysis in turbomachinery by advanced vibration analysis," Proceedings of the 1997 International Conference on Maintenance and Reliability, Knoxville (USA), vol. 1, pp. 7.01-7.14

[69] A.A. Da Silva et al., "Rotating machinery monitoring and diagnosis using short-lime Fourier transform and wavelet techniques," Proceedings of the 1997 International Conference on Maintenance and Reliability, Knoxville (USA), vol. 1, pp. 14.01-14.15.
[70] W. Wang et $a l$., "Detecting bearing defects under severe signal to noise ratio conditions," Proceedings of the 1997 international Conference on Maintenance and Reliability, Knoxville (USA), vol. 1, pp. 18.01- 12.12

[71] A.H. Bonnett et al., "The cause and analysis of stator and rotor failures in AC induction machines," Proceedings of the 1997 International Conference on Maintenance and Reliability, Knoxville (USA), vol. 1, pp. 29.01-29.20.

[72] F.M. Discenzo et al., "Motor diagnostics: Technological drivers leading to 21st century predictive diagnostics," Proceedings of the 1997 International Conference on Maintenance and Reliability, Knoxville, Tennessee (USA), vol. 1, pp. 30.01-30.12.

[73] J. Kapler et al., "A continuous on-line partial discharge monitor for 4kV motor stator winding," Proceedings of the 1997 International Conference on Maintenance and Reliability, Knoxville (USA), vol. 1 pp. 34.01-35.08.

[74] N.M.A. Ayad et al., "Expert system for electric motor fault diagnosis and treatment," Proceedings of the 1997 International Conference on Maintenance and Reliability, Knoxville (USA), vol. 1, pp. 35.01-35.13.

[75] M.E.H. Benbouzid et al., "Induction motor diagnostics via stator current monitoring," Proceedings of the 1997 International Conference on Maintenance and Reliability, Knoxville (USA), vol. 1, pp. 36.01-36.10.

[76] J.C. Jung et al., "Development of an induction motor abnormality monitoring System (IMAMS) using power line signal analysis," Proceedings of the 1997 International Conference on Maintenance and Reliability, Knoxville (USA), vol. 1, pp. 39.01-39.15.

[77] J.J. Kuropatwinski et al., "Prediction of motor misalignment using neural networks," Proceedings of the 1997 International Conference on Maintenance and Reliability, Knoxville (USA), vol. 2, pp. 61.0160.13 .

[78] J. Boyce et al., "Pump motor vibration analysis and fault detection using artificial neural/fuzzy system," Proceedings of the 1997 International Conference on Maintenance and Reliability, Knoxville (USA), vol. 2, pp. 60.01-60.15.

[79] N.M. Burstein, "Case histories of rotating equipment condition assessment by electric signal analysis," Proceedings of the 1997 International Conference on Maintenance and Reliability, Knoxville (USA), vol. 2, pp. 88.01-88.07.

[80] C.M. Riley et al., "Stator current-based sensorless vibration monitoring of induction motors," Proceedings of the 1997 IEEE Applied Power Electronics Conference, Anaheim (USA), vol. 1, pp. 142-147.

[81] F. Filippetti et al., "Deterministic approach and neural network approach for stator short circuits diagnosis in induction machines," Proceedings of the 1997 European Power Electronics Conference, Trondheim (Norway).

[82] B. Li et al., "Knowledge based technique to enhance the performance of neural network based motor fault detectors," Proceedings of the 1997 International Conference of the IEEE Industrial Electronics Society, New Orleans (USA), vol. 3, pp. 1113-1118.

[83] M.F. Abdel-Magied et al., "Fault detection of rotating machinery using model-based techniques," Proceedings of the 1997 International Conference of the IEEE Industrial Electronics Society, New Orleans (USA), vol. 1, pp. 27-33.

[84] S. Caldara et al., "A fuzzy diagnostic System: application to linear induction motor drives," Proceedings of the 1997 IEEE Instrumentation and Measurement Technology Conference, Ottawa (Canada), vol. 1, pp. 257-262.

[85] G.B. Kliman et al., "Sensorless approach to on-line motor diagnostics," Proceedings of the 1997 IEEE IAS Cement Industry Technical Conference, Hershey (USA), pp. 135-140.

[86] K. Ayandokun et $a l$., "Smart bearings: developing a new technique for the condition monitoring of rotating machinery," Proceedings of the 1997 IEEE International Conference on Intelligent Engineering Systems, pp. 505-510

[87] L. Zhao et al., " Combination of discrete cosine transform with neural network in fault diagnosis for rotating machinery," Proceedings of the 1996 IEEE International Conference on Industrial Technology, pp. $450-454$. 
[88] R. Fiser et al., "Modelling of dynamic performance of induction machine with rotor faults," Proceedings of the 1996 International Conference on Electrical Machines, Vigo (Spain), vol. 1, pp. 17-22.

[89] S.T. Manolas et al., "Analysis of squirrel cage induction motors with broken bars," Proceedings of the 1996 International Conference on Electrical Machines, Vigo (Spain), vol. 1, pp. 23-28.

[90] T. Sobczyk et al., "Models for induction motors with air-gap asymmetry for diagnostic purposes," Proceedings of the 1996 International Conference on Electrical Machines, Vigo (Spain), vol 1, pp. 78-84.

[91] C. Izquierdo et al., "Operational life of squirrel-cage rotors for HV induction motor," Proceedings of the 1996 International Conference on Electrical Machines, Vigo (Spain), vol. 1, pp. 306-308.

[92] H. Yahoui et al., "Analysis of the electromagnetic torque of an asynchronous motor with an end-ring fault," Proceedings of the 1996 International Conference on Electrical Machines, Vigo (Spain), vol. 1, pp. 396-400.

[93] S.J. Salon et al., "Effects of stator and rotor core ovality on induction machine behavior," Proceedings of the 1996 International Conference on Electrical Machines, Vigo (Spain), vol. 1, pp. 401-404.

[94] F. Filippetti et $a l$., "A simplified model of induction motors with stator shorted turns oriented to diagnostics," Proceedings of the 1996 International Conference on Electrical Machines, Vigo (Spain), vol. 1, pp. 410-413.

[95] F. Filippetti et al., "Impact of speed ripple on rotor fault diagnosis of induction machines," Proceedings of the 1996 International Conference on Electrical Machines, Vigo (Spain), vol. 1, pp. 452 457.

[96] D.G. Dorrell et al., "The causes and quantification of sideband currents for use in rotor fault detection systems in cage induction motors," Proceedings of the 1996 International Conference on Electrical Machines, Vigo (Spain).

[97] J. Rusek, "Reflection of eccentricities in spectral composition of current of induction machines," Proceedings of the 1996 International Conference on Electrical Machines, Vigo (Spain).

[98] M.F. Cabanas et al., "Shaft misalignment diagnosis of induction motors using current spectral analysis: A theoretical approach," Proceedings of the 1996 International Conference on Electrical Machines, Vigo (Spain).

[99] R. Belmans et al., "Different approaches to the preventive maintenance of induction motors," Proceedings of the 1996 International Conference on Electrical Machines, Vigo (Spain), vol 2, pp. 423-428.

[100] C. Peng et al., "Self-reorganization method of symptom parameters for failure diagnosis by genetic algorithms," Proceedings of the 1996 International Conference of the IEEE Industrial Electronics Society, vol. 2, pp. 829-835.

[101] F. Filippeti et al., "Neural network architecture for fault diagnosis and parameter recognition in induction machines," Proceedings of the 1996 IEEE Mediterranean Electrotechnical Conference, Bari (Italy), vol. 1, pp. 289-293.

[102] L. Collamati et al., "Induction machine stator fault on-line diagnosis based on LabView environment," Proceedings of the 1996 IEEE Mediterranean Electrotechnical Conference, Bari (Italy), vol. 1, pp. 495-498.

[103] R. Fiser et al., "Modelling of failure states of induction machines," Proceedings of the 1996 IEEE Mediterranean Electrotechnical Conference, Bari (Italy), vol. 3, pp. 1195-1198.

[104] J.R. Nicholas, Jr., "Off-line and on-line motor electrical monitoring and condition analysis: Payoffs and problems," Proceedings of the 1996 Meeting of the Society for Machinery Failure Prevention Technology, pp. 651-660.

[105] H. Yahoui et al., "Measurement of physical signals in rotating part of electrical machine by means of optical fiber transmission," Proceedings of the 1996 IEEE Instrumentation and Measurement Technology Conference, Brussels (Belgium), vol. 1, pp. 591-596.

[106] G. Betta et al., "The use of genetic algorithms for advanced instrument fault detection and isolation schemes," Proceedings of the 1996 IEEE Instrumentation and Measurement Technology Conference, Brussels (Belgium), vol. 2, pp. 1129-1134.
[107] J.F.G. de Freitas et al., "Identification of vibrating structures and fault detection using neural networks," Proceedings of the 1996 IEEE International Conference on Neural Networks, vol. 4, pp. 2044-2048.

[108] P.J. Chrzan et al., "Fault diagnosis of voltage-fed inverter for induction motor drive," Proceedings of the 1996 IEEE International Symposium on Industrial Electronics, Warsaw (Poland), vol. 2, pp. 1011-1016.

[109] W. Yousheng et al., "The application of wavelet transform and artificial neural networks in machinery fault diagnosis," Proceedings of the 1996 IEEE International Conference on Signal Processing, vol. 2, 1609-1612.

[110] F. Filippetti et $a l$., "AI techniques in induction machines diagnosis including the speed ripple effect," Proceedings of the 1996 IEEE IAS Annual Meeting, Lake Buena Vista (USA), vol. 1, pp. 655-662.

[111] T.W.S. Chow, "Condition monitoring of electric machines using thirdorder spectrum analysis," Proceedings of the 1996 IEEE IAS Annual Meeting, Lake Buena Vista (USA), vol. 1, pp. 679-686.

[112] G.B. Kliman et al., "A new approach to on-line turn fault detection in AC motors," Proceedings of the 1996 IEEE IAS Annual Meeting, Lake Buena Vista (USA), vol. 1, pp. 687-693.

[113] T.B. Breen et al., " New developments in noninvasive on-line motor diagnostics," Proceedings of the 1996 IEEE IAS Petroleum and Chemical Industry Conference, Banff (Canada), pp. 231-236.

[114] F. Filippetti et al., "A survey of neural network approach for induction machine on-line diagnosis," Proceedings of the 1996 Universities of Power Engineering Conference, Iraklio (Greece), vol. 1, pp. 17-20.

[115] F. Filippetti et al., "A survey of AI techniques approach for induction machine on-line diagnosis," Proceedings of the 1996 International Conference on Power Electronics and Motion Control, Budapest (Hungary), vol. 6, pp. 314-318.

[116] J.E. Timperley, "Detecting motor stator defects with on-line EMI analysis," Proceedings of the 1996 International Conference on Generator and Motor Partial Discharge Testing, Houston (USA), Paper 20

[117] K.D. Hurst et al., "A self-tuning thermal protection scheme for induction machines," Proceedings of the 1996 IEEE Power Electronics Specialists Conference, Baveno (Italy), vol. 2, pp. 1535 1541

[118] D.D. Wang et al., "Fault detection based on evolving LVQ neural networks," Proceedings of the 1996 International Conference on Systems, Man and Cybernetics, Beijing (China), vol. 1, pp. 255-260.

[119] J.M. Spanjaard et al., "Periodic autoregressive time-frequency analysis for monitoring of rotating machinery with variable period," Proceedings of the 1996 IEEE Signal Processing International Symposium on Time-Frequency and Time-Scale Analysis, pp. 465468.

[120] B.G. Hyun et al., "Faults diagnoses of rotating machines by using neural nets: GRNN and BPN," Proceedings of the 1995 International Conference of the IEEE Industrial Electronics Society, Florida (USA), vol. 2, pp., 1456-1461.

[121] M. Tanaka et al., "Application of Kohonen's self-organizing network to the diagnosis system for rotating machinery," Proceedings of the 1995 IEEE International Conference on Systems, Man and Cybernetics, vol. 5, pp. 4039-4044.

[122] G. Franceschini et al., "A global instrument for on-line induction motor integrity assessment," Proceedings of the 1995 IEEE International PowerTech Conference, Stockholm (Sweden), vol. EMD, pp. 86-90.

[123] F. Filippetti et al., "A fuzzy logic approach to on-line induction motor diagnostics based on stator current monitoring," Proceedings of the 1995 IEEE International PowerTech Conference, Stockholm (Sweden), vol. EMD, pp. 156-161.

[124] S. Ferkolj et al., "On-line fault diagnostic techniques of induction motor drives," Proceedings of the 1995 IEEE International PowerTech Conference, Stockholm (Sweden), vol. EMD, pp. 162 166.

[125] D.G. Dorrell, "The sources and characteristics of unbalanced magnetic pull in cage induction motors with either static or dynamic rotor eccentricity," Proceedings of the 1995 IEEE International PowerTech Conference, Stockholm (Sweden), vol. EMD, pp. 229-234. 
[126] X. Deng et al., "Rotor fault analysis of induction motors by dynamic model and finite element method," Proceedings of the 1995 IEEE International PowerTech Conference, Stockholm (Sweden), vol. EMD, pp. 368-372.

[127] F. Filippetti et al., "A LabView based virtual instrument for on-line induction motor parameters identification," Proceedings of the 1995 IEEE International Symposium on Industrial Electronics, Athens (Greece), vol. 2, pp. 648-653.

[128] N.A. Fountas et al., "Interactive transient analysis of unsymmetrical faults in industrial plants," Proceedings of the 1995 IEEE International Symposium on Industrial Electronics, Athens (Greece), vol. 2, pp. 908-913.

[129] A.J.M. Cardoso, "Rotor cage fault diagnosis in three-phase induction motors, by Park's vector approach," Proceedings of the 1995 IEEE IAS Annual Meeting, San Diego (USA), pp. 642-646.

[130] D.G. Dorrell et al., "Analysis of air-gap flux, current and vibration signals as a function of the combination of static and dynamic eccentricity in three-phase induction motors," Proceedings of the 1995 IEEE IAS Annual Meeting, San Diego (USA), vol. 1, pp. 563570.

[131] H.A. Toliyat et al., "A method for dynamic simulation and detection of air-gap eccentricity in induction machines," Proceedings of the 1995 IEEE IAS Annual Meeting, San Diego (USA), vol. 1, pp. 629-636.

[132] M. Rokonuzzaman et al., "Neural network based incipient fault detection of induction motors," Proceedings of the 1995 IEEE International Conference on Industrial Automation and Control, pp. 199-202.

[133] N.M. Roehl et al., "Fuzzy ART neural network approach for incipient fault detection and isolation in rotating machines," Proceedings of the 1995 IEEE International Conference on Neural Networks, vol. 1, pp. 538-542.

[134] D.G. Dorrell et al., "Combined effects of static and dynamic eccentricity on air-gap flux waves and the application of current monitoring to detect dynamic eccentricity in three-phase induction motors," Proceedings of the 1995 IEE Electrical Machines and Drives Conference, pp. 151-155.

[135] R. Burnett et al., "The current analysis program - A software tool for rotor fault detection in three phase induction motors," Proceedings of the 1995 IEE Electrical Machines and Drives Conference, pp. 156-160.

[136] C. Boyle et al., "On-line current monitoring to detect misalignment and dynamic eccentricity in three-phase induction motor drives," Proceedings of the 1995 Universities of Power Engineering Conference, London (UK), vol. 1, pp. 5-9.

[137] F. Filippetti et al., "Neural networks aided on-line diagnostics of induction machine stator fault," Proceedings of the 1995 Universities of Power Engineering Conference, London (UK), vol. 1, pp. 148-151.

[138] T. Koishi et al., "An analysis of a model base signal for trouble detection in electric machines," Proceedings of the 1995 International Conference of the IEEE Industrial Electronics Society, Orlando (USA), vol. 2, pp. 1073-1078

[139] B. Torres et al., "Real time parameters estimation of an induction motor," Proceedings of the 1995 International Power Electronics Congress, pp. 29-32.

[140] A.G. Bolton et al., "Diagnosing electrical and electronic systems in an intelligent environment," Proceedings of the 1995 Electronic Technology Directions to the Year 2000 Conference, pp. 217-225.

[141] M.F. Cabanas et al. "Detection of induction machine incipient failures using knowledge based techniques," Proceedings of the 1995 European Power Electronics Conference, Seville (Spain), vol. 1, p. 1024.

[142] P. Vas et al., "Transient modeling oriented to diagnostics of induction machines," Proceedings of the 1994 International Conference on Electrical Machines, Paris (France), vol. 2, pp. 62-67.

[143] J.T. Holbøll et al., "Motor insulation diagnostics by high frequency PD detection," Proceedings of the 1994 International Conference on Electrical Machines, Paris (France), vol. 2, pp. 68-72.

[144] W.T. Thomson, "On-line current monitoring to diagnose shaft misalignment in three-phase induction Motor drive systems," Proceedings of the 1994 International Conference on Electrical Machines, Paris (France), vol. 2, pp. 238-243.
[145] J. Penman et al., "Shorted turn detection and location in operating motors," Proceedings of the 1994 International Conference on Electrical Machines, Paris (France), vol. 2, pp. 252-255.

[146] D.G. Edwards et al., "Interpretation of slot discharge measurements on high voltage rotating machines," Proceedings of the 1994 International Conference on Electrical Machines, Paris (France), vol. 2, pp. 256-260.

[147] A. Stavrou et al., "The on-line quantification of air-gap eccentricity in induction machines," Proceedings of the 1994 International Conference on Electrical Machines, Paris (France), vol. 2, pp. 261266.

[148] R. Hirvonen, "On-line condition monitoring of defects in squirrel cage motors," Proceedings of the 1994 International Conference on Electrical Machines, Paris (France), vol. 2, pp. 267-272.

[149] R.R. Schoen et al., "A new method of current-based condition monitoring in induction machines operating under arbitrary load conditions," Proceedings of the 1994 International Conference on Electrical Machines, Paris (France), vol. 2, pp. 282-287.

[150] R. Burnett et al., "The detection and location of rotor faults within three phase induction motors," Proceedings of the 1994 International Conference on Electrical Machines, Paris (France), vol. 2, pp. 288293.

[151] A.G. Innes et al., "The detection of broken rotor bars in variable speed induction motor drives," Proceedings of the 1994 International Conference on Electrical Machines, Paris (France), vol. 2, pp. 294298.

[152] E. Ritchie et al., "Diagnosis of rotor faults in squirrel cage induction motors using a fuzzy logic approach," Proceedings of the 1994 International Conference on Electrical Machines, Paris (France), vol. 2, pp. 348-352.

[153] J. Penman et al., "Machine diagnostics with ANN's: Possibilities and problems," Proceedings of the 1994 International Conference on Electrical Machines, Paris (France), vol. 2, pp. 363-368.

[154] G. Cirrincione et al., "A Kohonen neural network for the diagnosis in induction motors," Proceedings of the 1994 International Conference on Electrical Machines, Paris (France), vol. 2, pp. 369-373.

[155] G.H. Miller et al., "Vibration produced in squirrel cage induction motors having broken rotor bars and interbar currents," Proceedings of the 1994 International Conference on Electrical Machines, Paris (France), vol. 2, pp. 595-600.

[156] E. Ritchie et al., "Dynamic model of three-phase squirrel cage induction motors with rotor faults," Proceedings of the 1994 International Conference on Electrical Machines, Paris (France), vol. 2, pp. 694-698

[157] G. Bucci et al., "Special measurement system for on-line fault diagnosis of induction motors," Proceedings of the 1994 International Conference of the IEEE Industrial Electronics Society, Bologna (Italy), vol. 3, pp. 1794-1798.

[158] A.R. Munoz et al., "Magnetic vibration of three-phase induction motors supplied by inverters," Proceedings of the 1994 IEEE International Symposium on Industrial Electronics, Santiago (Chile), pp. 210-213.

[159] R. Di Stefano et al., "Induction motor faults diagnostic via artificial neural network (ANN)," Proceedings of the 1994 IEEE International Symposium on Industrial Electronics, Santiago (Chile), pp. 220.225.

[160] F. Filippetti et al., "Broken bar detection in induction machines: comparison between current spectrum approach and parameter estimation approach," Proceedings of the 1994 IEEE IAS Annual Meeting, Denver (USA), vol. 1, pp. 95-102.

[161] T.G. Habetler et al., "An integrated on-line motor protection system," Proceedings of the 1994 IEEE IAS Annual Meeting, Denver (USA), vol. 1, pp. 117-122

[162] O.V. Thorsen, "Development and industrial application of a practical model for simulation of saturated deep bar induction machines," Proceedings of the 1994 IEEE IAS Annual Meeting, Denver (USA), vol. 1, pp. 137-142.

[163] M.Y. Chow, "The advantages of machine fault detection using artificial neural network and fuzzy logic technologies," Proceedings of the 1994 IEEE International Conference on Industrial Technology, Guangzhou (China), pp. 83-87. 
[164] C. Zhang et al., "On-line incipient fault detection of induction motors using artificial neural networks," Proceedings of the 1994 IEEE International Conference on Industrial Technology, Guangzhou (China), pp. 458-462.

[165] P.V. Goode et al., "A hybrid fuzzy/neural system used to extract heuristic knowledge from a fault detection problem," Proceedings of the 1994 IEEE World Congress on Computational intelligence, Orlando (USA), vol. 3, pp. 1731-1736.

[166] G. Dorrell, "The effects of dynamic eccentricity in cage induction motors," Proceedings of the 1994 Universities of Power Engineering Conference, Galway (Ireland), vol. 1, pp. 402-405.

[167] W.T. Thomson, "On-line current monitoring to detect electrical and mechanical faults in three-phase induction motors," Proceedings of the 1994 IEE International Conference on Life Management of Power Plant, London (UK), pp. 66-74.

[168] D.G. Edwards, "Planned maintenance of high voltage rotating machine insulation based upon information derived from on-line discharge measurements," Proceedings of the 1994 IEE International Conference on Life Management of Power Plant, London (UK), pp. 101-107.

[169] B.A. Lloyd et al., "Motor insulation condition assessment using expert systems software," Proceedings of the 1994 IEEE Pulp and Paper Industry Technical Conference, Nashville (USA), pp. 60-67.

[170] R. Munoz et al., "Mechanical vibration of three-phase induction motors fed by nonsinusoidal currents," Proceedings of the 1994 International Power Electronics Congress, vol. 1, pp. 166-172.

[171] G. Gentile et al., "AC machines performances in faulted operations," Proceedings of the 1994 Mediterranean Electrotechnical Conference, Antalya (Turkey), ,vol. 3, pp. 1283-1286.

[172] P.V. Goode et al., "Neural/fuzzy systems for incipient fault detection in induction motors," Proceedings of the 1993 International Conference of the IEEE Industrial Electronics Society, Maui (USA)

[173] F. Filippetti et al., "Neural network approach to electric machine on line diagnosis," Proceedings of the 1993 European Power Electronics Conference, Brighton (UK), vol. 1, pp. 213-218.

[174] K. Nam et al., "Diagnosis of rotating machines by utilizing a backpropagation neural network," Proceedings of the 1992 International Conference of the IEEE Industrial Electronics Society, San Diego (USA), vol. 2, pp. 1064-1067.

[175] M.Y. Chow et al., "Design consideration for a motor fault detection artificial neural network," Proceedings of the 1992 International Conference of the IEEE Industrial Electronics Society, San Diego (USA).

[176] S. Salon et al., "Calculation of circulating current between parallel winding in induction motors with eccentric rotors by finite element method," Proceedings of the 1992 International Conference on Electrical Machines, Manchester (UK), vol. 1, pp. 371-375.

[177] P. Vas, "Simulation and monitoring of induction motors with rotor asymmetry," Proceedings of the 1992 International Conference on Electrical Machines, Manchester (UK).

[178] W.T. Thomson, "On line current monitoring the influence on mechanical load or an unique design on the diagnosis of broken bars in induction motors," Proceedings of the 1992 International Conference on Electrical Machines, Manchester (UK), vol. 3, pp. 1236-1240.

[179] J.F. Watson et al., "Transient analysis of the line current as a fault detection technique for three phase induction motors," Proceedings of the 1992 International Conference on Electrical Machines, Manchester (UK). vol. 3, pp. 1241-1245.

[180] R.F. Walliser et al., "The influence of interbar currents on the detection of broken rotor bar," Proceedings of the 1992 International Conference on Electrical Machines, Manchester (UK), vol. 3, pp. 1246-1250.

[181] J. Penman et al., "The application of artificial neural networks in identify faults in induction machines," Proceedings of the 1992 International Conference on Electrical Machines, Manchester (UK), vol. 3, pp. 1256-1260.

[182] D.G. Edwards, "On-line diagnosis of defects in stator winding insulation structures of high-voltage rotating machines," Proceedings of the 1992 International Conference on Electrical Machines, Manchester (UK), vol. 3, pp. 1299-1303.
[183] W. Rams et al., "Stator yoke elliptic deformation of AC machines as winding fault indicator," Proceedings of the 1992 International Conference on Electrical Machines, Manchester (UK), vol. 3, pp. 1304-1308.

[184] F. Filippetti et al., "Development of expert system knowledge base to on-line diagnosis of rotor electrical faults of induction motors," Proceedings of the 1992 IEEE IAS Annual Meeting, Houston (USA), pp. 92-99.

[185] P. Lo et al., "Stator insulation monitoring of large high voltage motors and generators using on-line RF techniques in the petrochemical environment," Proceedings of the 1992 IEEE Petroleum and Chemical Industry Technical Conference, San Antonio (USA), pp. 177-183.

[186] C.H. Nowlin, "An analysis of the relationship between induction motor current and shaft speed fluctuations," Proceedings of the 1992 Meeting of the Society for Machinery Failure Prevention Technology, pp. 253-262.

[187] S.F. Smith et al., "Advanced techniques in current signature analysis," Proceedings of the 1992 Meeting of the Society for Machinery Failure Prevention Technology, pp. 263-276.

[188] M. Tinston et al., "Motor current analysis for the diagnosis of air compressor defects," Proceedings of the 1992 Meeting of the Society for Machinery Failure Prevention Technology, pp. 291-300.

[189] G.B. Kliman et al., "The limits of motor current signature analysis," Proceedings of the 1992 Meeting of the Society for Machinery Failure Prevention Technology, pp. 301-310.

[190] G. Gentile et al., "Diagnostic indexes for knowledge base representation of induction machines stator short circuits," Proceedings of the 1991 European Power Electronics Conference, Firenze (Italy), vol. 4, pp. 312-317.

[191] D. Leith et $a l$. ., "Real time expert system for identifying rotor faults and mechanical influences in induction motor phase current," Proceedings of the 1991 IEE International Conference on Electrical Machines, Drives and Application, London (UK), pp. 46-50.

[192] A.J.M. Cardoso et al., "On-line detection of airgap eccentricity in three-phase induction motors by Park's vector approach," Proceedings of the 1991 IEE International Conference on Electrical Machines, Drives and Application, London (UK), pp. 61-66.

[193] I.D. Lomax, "Assessment of induction motor cage fatigue life," Proceedings of the 1991 IEE International Conference on Electrical Machines, Drives and Application, London (UK), pp. 281-284.

[194] M.Y. Chow et al., "Application of learning theory to a single phase induction motor incipient fault detection artificial neural network," Proceedings of the 1991 International Joint Conference on Neural Networks, Seattle (USA), pp. 97-101.

[195] M.Y. Chow et al., "Robustness test of an incipient fault detector artificial neural network," Proceedings of the 1991 International Joint Conference on Neural Networks, Seattle (USA), pp. 173-178.

[196] G.B. Kliman et al., "Induction motor fault detection via passive current monitoring," Proceedings of the 1990 International Conference on Electrical Machines, Cambridge (USA), vol. 1, pp. 1317

[197] G. Gentile et al., "Analysis of induction motor stator faults to on-line diagnostics," Proceedings of the 1990 International Conference on Electrical Machines, Cambridge (USA), vol. 2, pp. 491-497.

[198] C.F. Landy et al., "The effect of broken rotor bars on the torque speed curve of squirrel cage induction motors," Proceedings of the 1990 International Conference on Electrical Machines, Cambridge (USA), vol. 2, pp. 510-515.

[199] A.J.M. Cardoso et al., "On-line diagnostics of currents source inverter-fed induction machines by Park's vector approach," Proceedings of the 1990 International Conference on Electrical Machines, Cambridge (USA), vol. 3, pp. 1000-1005.

[200] G.B. Kliman et al., "Induction motor fault detection via passive current monitoring - A brief survey," Proceedings of the 1990 Meeting of the Society for Machinery Failure Prevention Technology, Virginia Beach (USA), pp. 49-99.

[201] C.L. Thibault, "Motor current signature analysis - MCSA," Proceedings of the 1990 Meeting of the Society for Machinery Failure Prevention Technology, Virginia Beach (USA), pp. 73-80. 
[202] D.J. Linehan et al., "Cost-effective on-line monitoring of rotating equipment using motor current analysis," Proceedings of the 1990 Meeting of the Society for Machinery Failure Prevention Technology, Virginia Beach (USA), pp. 81-86.

[203] S.F. Smith et al., "Machine monitoring via motor-current demodulation techniques," Proceedings of the 1990 Meeting of the Society for Machinery Failure Prevention Technology, Virginia (USA), pp. 87-96.

[204] J. H. Kohler et al., "Incipient failure prediction for electrical machines," Proceedings of the 1990 Meeting of the Society for Machinery Failure Prevention Technology, Virginia Beach (USA), pp. 97-110.

[205] J. Reis, "Case study of a method for diagnosing AC induction motors using spectrum analysis," Proceedings of the 1989 International Machinery Monitoring and Diagnostic Conference, pp. 40-44.

[206] G.B. Kliman et al., "Broken bar detector for squirrel cage induction motors," Proceedings of the 1989 International Machinery Monitoring and Diagnostic Conference, pp. 674-682.

[207] P.J. Tavner, "Condition monitoring-The way ahead for large electrical machines," Proceedings of the 1989 IEE International Conference on Electrical Machines, Drives and Application, London (UK), pp. 159162.

[208] S. Fruchtenicht et al., "A diagnostic system for three-phase asynchronous machines," Proceedings of the 1989 IEE International Conference on Electrical Machines, Drives and Application, London (UK), pp. 163-171.

[209] A.J.M. Cardoso et al., "On-line diagnostics of three-phase induction motors," Proceedings of the 1988 International Conference on Electrical Machines, Pisa (Italy), vol. 3, pp. 231-234.

[210] F. Filippetti et al., "An approach to the knowledge representation about induction machine diagnostics in expert systems," Proceedings of the 1988 International Conference on Electrical Machines, Pisa (Italy), vol. 3, pp. 289-296.

[211] D. Leith et al., "Condition monitoring of electrical machines using real-time expert system," Proceedings of the 1988 International Conference on Electrical Machines, Pisa (Italy), vol. 3, pp. 297-302.

[212] W. Deleroi, "The analytical solution of an unsymmetrical rotating field machine for transients as an example of a two phase short-circuit," Proceedings of the 1988 International Conference on Electrical Machines, Pisa (Italy), vol. 3, pp. 537-541.

[213] W.D. Strunk, "Consideration for the establishment of a machinery monitoring and analysis program for surface ships of the US Navy," Proceedings of the 1988 International Modal Analysis Conference, Schenectady (USA), pp. 914-920.

[214] P.J. Tavner et al., "An electrical technique for monitoring induction motor cage," Proceedings of the 1987 IEE International Conference on Electrical Machines, Drives and Application, London (UK), pp. 43-46.

[215] J.R. Cameron et al., "On-line current monitoring of induction motors A method for calculating the level of airgap eccentricity," Proceeding of the 1987 IEE International Conference on Electrical Machines, Drives and Application, London (UK), pp. 173-178.

[216] W.T. Thomson et al., "Case histories of rotor winding fault diagnosis in induction motors," Proceedings of the 1987 International Conference on Condition Monitoring, Swansea (UK), pp. 798-819.

[217] N.M. Elkasabgy et al., "The detection and effects of broken bars in cage rotor induction machines," Proceedings of the 1986 IEEE Workshop on Electromagnetic Field Computation, Schenectady (USA), pp. 24-28

[218] W.T. Thomson et al., "Monitoring strategy for discriminating between different types of rotor defects in induction motors," Proceedings of the 1983 Universities Power Engineering Conference, Guilford (UK), pp. 241-246.

[219] S.P. Verma et al., "Effects of eccentricity in induction machines," Proceedings of the 1982 International Conference on Electrical Machines, Budapest (Hungary), vol. 3, pp. 930-933.

[220] C. Hargis et al., "The detection of rotor defects in induction motors," Proceedings of the 1982 IEE International Conference on Electrical Machines, Design and Application, London (UK), pp. 216-220.
[221] M.E. Steele et al., "An electrical method for condition monitoring of motors," Proceedings of the 1982 IEE International Conference on Electrical Machines, Design and Application, London (UK), pp. 231-235.

[222] J. Penman et al., "Protection strategy against the occurrence of faults in electrical machines," Proceedings of the 1982 IEE International Conference on Electrical Machines, Design and Application, London (UK), pp. 54-5 8

\section{Journal Papers}

[223] M.A. Cash et al., "Insulation failure prediction in AC machines using line-neutral voltages," IEEE Trans. Industry Applications, vol. 34 n6, November-December 1998, pp. 1234-1239.

[224] C.M. Riley et al., "A method for sensorless on-line vibration monitoring of induction machines," IEEE Trans. Industry Applications, vol. 34, n6, November-December 1998, pp. 1240-1245.

[225] A. Bethge et al., "On-line monitoring of partial discharge on stator winding of large rotating machines in the petrochemical environment," IEEE Trans. Industry Applications, vol. 34, n 6 , November-December 1998, pp. 1359-1365.

[226] J.H. Dymond, "Sparking, electrical discharge, and heating in synchronous and induction machines: Can it be controlled ?," IEEE Trans. Industry Applications, vol. 34, n6, November-December 1998, pp. 1371-1377.

[227] S. Chen et al., "Bearings currents and shaft voltages of an induction motor under hard- and soft-switching inverter excitation," IEEE Trans. Industry Applications, vol. 34, n5, September-October 1998, pp. $1042-1048$

[228] T. Thorsen et al., "Methods of condition monitoring and fault diagnosis for induction motors," European Trans. Electrical Power, vol. 8, n5, September-October 1998, pp. 383-395.

[229] J.F. Bangura et al., "Diagnosis and characterization of effects of broken bars and connectors in squirrel-cage induction motors by a time-stepping coupled finite element-state space modeling approach," IEEE Trans. Energy Conversion, PE-449-EC-0-07-1998.

[230] M.E.H. Benbouzid et al., "Induction motor asymmetrical faults detection using advanced signal processing techniques," IEEE Trans. Energy Conversion, PE-094-EC-0-2-1998.

[231] M.E.H. Benbouzid et al., "Induction motors thermal monitoring by means of rotor resistance identification," IEEE Trans. Energy Conversion, PE-I155-EC-0-2-1998.

[232] S.J. Manolas et al., "Analysis of squirrel cage induction motors with broken bars and rings," IEEE Trans. Energy Conversion, PE-I214EC-0-2-1998.

[233] W.T. Thomson et al., "Online current monitoring to diagnose airgap eccentricity in large three phase induction motors: Industrial case histories verify the predictions," IEEE Trans. Energy Conversion, PEI263-EC-0-2-1998.

[234] A.M. Trzynadlowski et al., "Diagnostics of mechanical abnormalities in induction motors using instantaneous electric power," IEEE Trans. Energy Conversion, PE-I263-EC-0-2-1998.

[235] Y. Takezawa et al., " Development of a portable diagnostic apparatus for coil insulators in low-voltage induction motors," IEEE Trans. Dielectrics and Electrical Insulation, vol. 5, n², April 1998, pp. 290-295.

[236] M.S. Rajagopal et al., "Transient thermal analysis of induction motors," IEEE Trans. Energy Conversion, vol. 13, n 1, March 1998, pp. 62-69.

[237] M.E.H. Benbouzid et al., "Induction motor interturn short-circuit and bearing wear detection using artificial neural networks," Electromotion, vol. 5, n², January-June 1998, pp. 15-20.

[238] G.C. Stone, "Partial discharge. XXV. Calibration of PD measurement for motor and generator windings - Why it can't be done," IEEE Electrical Insulation Magazine, vol. 14, n¹, January-February 1998, pp. 9-12.

[239] F. Filippetti et al., "AI techniques in induction machines diagnosis including the speed ripple effect," IEEE Trans. Industry Applications, vol. 34, n 1 , January-February 1998, pp. 98-108.

[240] A.J.M. Cardoso et al., "Inter turn stator winding fault diagnosis in three phase induction motors, by Park's vector approach," IEEE Trans. Energy Conversion, PE-I166-EC-0-10-1997. 
[241] J.F. Watson et al., "The use of finite element methods to improve techniques for the early detection of faults in three-phase induction motors," IEEE Trans. Energy Conversion, PE-I270-EC-0-10-1997.

[242] M.Y. Chow, "Motor fault detection and diagnosis," IEEE Industrial Electronics Society Newsletter, vol. 42, December 1997, pp. 4-7.

[243] R.R. Schoen et al., "Evaluation and implementation of a system to eliminate arbitrary load effects in current-based monitoring of induction machines," IEEE Trans. Industry Applications, vol. 33, n 6 , November-December 1997, pp., 1571-1577.

[244] S. Williamson et al., "Rotor cage anomalies and unbalanced magnetic pull in single-phase induction motors," IEEE Trans. Industry Applications, vol. 33, n6, November-December 1997, pp. 1553-1562.

[245] S. Bell et al., "Will your motor insulation survive a new adjustablefrequency drive ?," IEEE Trans. Industry Applications, vol. 33, n5, September-October 1997, pp. 1307-1311.

[246] A. Murray et al., "Extracting useful higher order features for condition monitoring using artificial neural networks," IEEE Trans. Signal Processing, vol. 45, n¹1, November 1997, pp. 2821-2828.

[247] A.H. Bonnett, "A comparison between insulation systems available for PWM-inverter-fed motors," IEEE Trans. Industry Applications, vol. 33, n5, September-October 1997, pp. 1331-1341.

[248] J. Blattner et al., "Sensor-less, neuronal-network-based cage defect diagnosis for induction machines," European Trans. Electrical Power, vol. 7, n² 4, July-August 1997, pp. 281-286.

[249] W.H. Kersting et al., "Phase frame analysis of the effects of voltage unbalance on induction machines," IEEE Trans. Industry Applications, vol. 33, n², March-April 1997, pp. 415-420.

[250] D. Busse et al., "System electrical parameters and their effects on bearing currents," IEEE Trans. Industry Applications, vol. 33, n², March-April 1997, pp. 577-584

[251] D. Busse et al., "Bearing current and their relationship to PWM drives," IEEE Trans. Power Electronics, vol. 12, n², March 1997, pp. 243-252.

[252] G.B. Kliman et al., "Sensorless online motor diagnostics," IEEE Computer Applications in Power, vol., 10, n², April 1997, pp. 39-43.

[253] C.B. Rajanathan et al., "Electromechanical transients in a three-phase induction motor during phase failure and plugging," IEEE Trans. Magnetics, vol. 33, n², March 1997, pp. 1219-1222.

[254] C.E. Kim et al., "The fault diagnosis of rotor bars in squirrel cage induction motors by time stepping finite element method," IEEE Trans. Magnetics, vol. 33, n², March 1997, pp. 2131-2134.

[255] D.G. Dorrell et al., "Analysis of airgap flux, current, and vibration signals as a function of the combination of static and dynamic airgap eccentricity in three-phase induction motors," IEEE Trans. Industry Applications, vol. 33, n 1, January-February 1997, pp. 24-34.

[256] W.R. Finlay et al., "Proper specification and installation of induction motors," IEEE Industry Applications Magazine, vol. 31, n ${ }^{\circ}$, JanuaryFebruary 1997, pp. 56-69.

[257] N.M. Burstein et al., "Case histories of rotating equipment condition assessment by electric signal analysis," P/PM Technology, December 1996, pp. 36-39.

[258] A. Bernieri et al., "On-line fault detection and diagnosis obtained by implementing neural algorithms on a digital signal processor," IEEE Trans. Instrumentation and Measurement, vol. 45, n5, October 1996, pp. 894-899.

[259] M. Kaufhold et al., "Failure mechanism of the interturn insulation of low voltage electric machines fed by pulse-controlled inverters," IEEE Electrical Insulation Magazine, vol. 12, n5, September-October 1996, pp. 9-16.

[260] D.E. Schump, "Predict motor failure with insulation testing," Plant Eng., vol. 50, September 1996, pp. 94-96.

[261] G.C. Stone, "The use of partial discharge measurements to assess the condition of rotating machine insulation," IEEE Electrical Insulation Magazine, vol. 21, n6, July-August 1996, pp. 23-27.

[262] A. Mbaye et al., "Existence of partial discharges in low-voltage induction machines supplied by PWM drives," IEEE Trans. Dielectrics and Electrical Insulation, vol. 3, n4, August 1996, pp. 554-560.

[263] G.T. Homce et al., "Reducing unscheduled plant maintenance delays Field test of a new method to predict electric motor failure," IEEE Trans. Industry Applications, vol. 32, n³, May-June 1996, pp. 689-694.
[264] A.H. Bonnett, "Analysis of the impact of pulse-width modulated inverter voltage waveforms on AC induction motors," IEEE Trans. Industry Applications, vol. 32, n² ${ }^{\circ}$, March-April 1996, pp. 386-392.

[265] G.C. Stone et al., "Application of partial discharge testing to motor and generator stator winding maintenance," IEEE Trans. Industry Applications, vol. 32, n², March-April 1996, pp. 459-464.

[266] J.M. Erdman et al., "Effect of PWM inverters on AC motor bearing current and shaft voltages," IEEE Trans. Industry Applications, vol. 32, n², March-April 1996, pp. 250-259.

[267] S.F. Farag et al., "An integrated on-line motor protection system," IEEE Industry Applications Magazine, vol. 2, n², March-April 1996, pp. 21-26.

[268] S. Chen et al., "Source of induction motor bearing currents caused by PWM inverters," IEEE Trans. Energy Conversion, vol. 11, n 1 , March 1996, pp. 25-32.

[269] R. Burnett et al., "The application of modern signal processing techniques for use in rotor fault detection and location within threephase induction motors," European Signal Processing Journal, vol., 1, n 49, March 1996.

[270] G. Betta et al., "A knowledge-based approach to instrument fault detection and isolation," IEEE Trans. Instrumentation and Measurement, vol. 44, n6, December 1995, pp. 1009-1016.

[271] T.W.S. Chow et al., "Three phase induction machines asymmetrical faults identification using bispectrum," IEEE Trans. Energy Conversion, vol. 10, $\mathrm{n}^{\circ} 4$, December 1995, pp. 688-693.

[272] J.H. Dymond et al., "Some commentary on the choice of rotor bar material for induction motors," IEEE Trans. Energy Conversion, vol. 10, n³, September 1995, pp. 425-430.

[273] R.R. Schoen et al., "Motor bearing damage detection using stator current monitoring," IEEE Trans. Industry Applications, vol. 31, n6, November-December 1995, pp. 1274-1279.

[274] R.R. Schoen et al., "An unsupervised, on-line system for induction motor fault detection using stator current monitoring," IEEE Trans. Industry Applications, vol. 31, $\mathrm{n}^{\circ}$ 6, November-December 1995, pp., 1280-1286.

[275] J.S. Hsu, "Monitoring of defects in induction motors through air-gap torque observation," IEEE Trans. Industry Applications, vol. 31, n5, September-October 1995, pp. 1016-1021.

[276] O.V. Thorsen et al., "A survey of faults on induction motors in offshore oil industry, petrochemical industry, gas terminals, and oil refineries," IEEE Trans. Industry Applications, vol. 31, n5, September-October 1995, pp., 1186-1 196.

[277] F. Filippetti et al., "Neural networks aided on-line diagnostics of induction motor rotor faults," IEEE Trans. Industry Applications, vol. 31, n² 4uly-August 1995, pp. 892-899.

[278] R.R. Schoen et al., "Effects of time-varying loads on rotor fault detection in induction machines," IEEE Trans. Industry Applications, vol. 31, n4, July-August 1995, pp. 900-906.

[279] T. Bradatsch et al., "A parameter-identification-based diagnosis for detecting static air-gap eccentricity," European Trans. Electrical Power, vol. 5, n 4 , July-August 1995, pp. 273-278.

[280] J.A. Oliver et al., "Implication for the application of adjustable speed drive electronic to motor stator winding insulation," IEEE Electrical Insulation Magazine, vol. 11, n² 4, July-August 1995, pp. 32-36.

[281] R. Nelson et al., "Solution to motor insulation failures," Power Transmission Design, August 1995, pp. 43-46.

[282] H.A. Toliyat et al., "Transients analysis of cage induction machines under stator, rotor bar and end ring faults," IEEE Trans. Energy Conversion, vol. 10, n², June 1995, pp. 241-247.

[283] G.C. Stone et al., "In-service evaluation of motor and generator stator windings using partial discharge test," IEEE Trans. Industry Applications, vol. 31, n², March-April 1995, pp. 299-303.

[284] P.V. Goode et al., "Using a neural/fuzzy system to extract knowledge of incipient fault in induction motors Part I - Methodology," IEEE Trans. Industrial Electronics, vol. 42, n², April 1995, pp., 131-138.

[285] P.V. Goode et $a l$., "Using a neural/fuzzy system to extract knowledge of incipient fault in induction motors Part II - Application," IEEE Trans. Industrial Electronics, vol. 42, n² , April 1995, pp. 139-146.

[286] D. Rankin, "The industrial application of phase current analysis to detect winding faults in squirrel cage induction motors," IEE Power Engineering Journal, April 1995, pp. 77-84. 
[287] D. Zhou, "Study of on-line fault detection and diagnostics of three phase induction motors," Control Theory \& Applications, vol. 12, $\mathrm{n}^{\circ} 1$ February 1995, p. 63.

[288] T.S. Key, "Predicting behavior of induction motors during service faults and interruptions," IEEE Industry Applications Magazine, vol $1, \mathrm{n}^{\circ} 1$, January-February 1995, pp. 6-11.

[289] N.S. Feng et $a l$., "Including foundation effects on the vibration behaviour of rotating machinery," Mechanical Systems \& Signal Processing, vol. 9, n³, 1995, pp. 243-256.

[290] Y.S. Lee et al., "An acoustic diagnostic technique for use with electric machine insulation," IEEE Trans. Dielectrics and Electrical Insulation, vol. 1, $\mathrm{n}^{\circ}$ 6, December 1994, pp. 1 186-1 193.

[291] J. Penman et $a l$., "Feasibility of using unsupervised learning neural networks for the condition monitoring of electrical machines," IEE Proc., vol., 141, pt. B, nº ${ }^{\circ}$, November 1994, pp. 317-322.

[292] J. Penman et al., "Detection and location of interturn short circuits in the stator windings of operating motors," IEEE Trans. Energy Conversion, vol. 9, n4, December 1994, pp. 652-658.

[293] W.R. Finlay et al., "Troubleshooting motor problems," IEEE Trans. Industry Applications, vol. 30, n5, September-October 1994, pp., 1383-1397.

[294] S. Chen et al., "A new approach to motor condition monitoring in induction motor drives," IEEE Trans. Industry Applications, vol. 30 $\mathrm{n}^{\circ}$ 4, July-August 1994, pp. 905-911.

[295] J. Stephan et al., "Real-lime estimation of the parameters and fluxes of induction motors," IEEE Trans. Industry Applications, vol. 30, n³, May-June 1994, pp. 746-759

[296] W.N. Sharpe et al., "A methodology using fuzzy logic to optimize feedforward artificial neural network configurations," IEEE Trans. Systems, Man and Cybernetics, vol. 24, n6, May 1994, pp. 760-768.

[297] G. Gentile et al., "Harmonic analysis of induction motors with stator faults," Electric Machines \& Power Systems, vol. 22, n², March 1994, pp. 215-232.

[298] R.F. Walliser et al., "Determination of interbar current effects in the detection of broken bars in squirrel cage induction motors," IEEE Trans. Energy Conversion, vol. 9, n¹, March 1994, pp. 152-158.

[299] R.F. Walliser et al., "Assessment of interbar currents in double-cage induction motors with broken bars," IEEE Trans. Energy Conversion, vol. 9, n¹, March 1994, pp. 159-164.

[300] J. Sottile et al., "An on-line method to detect incipient failure of turn insulation in random-wound motors," IEEE Trans. Energy Conversion, vol. 8, n4, December 1993, pp. 762-768.

[301] F.C. Trutt et al., "Prediction of electrical behavior in deteriorating induction motors," IEEE Trans. Industry Applications, vol. 29, n 6 , November-December 1993, pp. 1239-1243.

[302] A.H. Bonnett, "Cause and analysis of antifriction bearing failures in AC induction motors," IEEE Industry Applications Society Newsletter, September-October 1993, pp. 14-23.

[303] A.J.M. Cardoso et al., "Computer-aided detection of airgap eccentricity in operating three-phase induction motors by Park's vector approach," IEEE Trans. Industry Applications, vol. 29, n5, September-October 1993, pp. 897-901.

[304] F. Thollon et al., "Asynchronous motor cage fault detection through electromagnetic torque measurement," European Trans. Electrical Power, vol. 3, n5, September-October 1993, pp. 375-378.

[305] I.E. Alguindigue et $a l .$, "Monitoring and diagnosis of rolling elemen bearings using artificial neural networks," IEEE Trans. Industrial Electronics, vol. 40, n², April 1993, pp. 209-217.

[306] M.Y. Chow et al., "On the application and design of artificial neura networks for motor fault detection - Part II," IEEE Trans. Industrial Electronics, vol. 40, n², April 1993, pp. 189-197.

[307] M.Y. Chow et al., "On the application and design of artificial neural networks for motor fault detection - Part I," IEEE Trans. Industrial Electronics, vol. 40, n², April 1993, pp. 181-188.

[308] M.J. Costello, "Shaft voltages and rotating machinery," IEEE Trans. Industry Applications, vol. 29, n², March-April 1993, pp. 419-426.

[309] M.J. DeBortolli et al., "Effects of rotor eccentricity and parallel windings on induction machine behaviour - A study using finite element analysis," IEEE Trans. Magnetics, vol. 29, n², March 1993, pp. 1676-1682.
[310] J.L. Kohler et al., "Alternatives for assessing the electrical integrity of induction motors," IEEE Trans. Industry Applications, vol. 28, n5, September-October 1992, pp. 1109-1117.

[311] K.R. Cho et al., "Detection of broken motor bars in induction motors using state and parameter estimation," IEEE Trans. Industry Applications, vol. 28, n³, May-June 1992, pp. 702-709.

[312] G.B. Kliman et al., "Methods of motor current signature analysis," Electric Machines \& Power Systems, vol. 20, n ${ }^{\circ}$, September 1992. pp. 463-474.

[313] A.H. Bonnett et al., "Cause and analysis of stator and motor failures in three-phase squirrel-cage induction motors," IEEE Trans. Industry Applications, vol. 28, n4, July-August 1992, pp. 921-937.

[314] N.M. Elkasabgy et al., "Detection of broken bars in the cage motor on an induction machine," IEEE Trans. Industry Applications, vol. 28, $\mathrm{n}^{\circ} 1$, January-February 1992, pp. 165-171.

[315] I. Morita, "Air gap flux analysis for cage motor diagnosis," Electrical Engineering Trans. of Japan, vol. 112, 1992.

[316] W.R. Finlay et al., '"Noise in induction motors - Causes and treatments," IEEE Trans. Industry Applications, vol. 27, nº6, November-December 1991

[317] M.Y. Chow et al., "A neural network approach to real-time condition monitoring of induction motors," IEEE Trans. Industrial Electronics, vol. 38, n6, December 1991, pp. 448-453.

[318] M.Y. Chow et al., "Using neural networks to detect incipient faults in induction motors," J. Neural Network Computing, vol. 2, n³, Winter 1991, pp. 26-32.

[319] M.Y. Chow et al., "Application of learning theory to a single phase induction motor incipient fault detection artificial neural network," Int. J. Neural Systems, vol. 2, n¹\&2, 1991, pp. 91-100.

[320] M.Y. Chow et al., "Methodology for on-line incipient fault detection in single-phase squirrel-cage induction motors using artificial neural networks," IEEE Trans. Energy Conversion, vol. 6, n³, September 1991, pp. 536-545.

[321] L. Qu et al., "Investigation of the spectral trending method for rotating machinery," Condition Monitoring Diagnostic Tech., vol. 1, n³, 1991, pp. 84-88.

[322] D.J.T. Siyambalapitiya et $a l$., "Reliability improvement and economic benefits of on-line monitoring system for large induction machines," IEEE Trans. Industry Applications, vol. 26, n4, July-August 1990, pp., 1018-1025.

[323] E. Krumpolc, "Bearing currents and shaft voltages in electric machines," Electrotechnik, vol. 45, n²4, April 1990, pp. 88-91.

[324] C.A. Protopapas et al., "An expert system for fault repairing and maintenance of electrical machines," IEEE Trans. Energy Conversion, vol. 5, n 1 , March 1990, pp. 79-83.

[325] J. Penman et $a l$., "Relationship between alternative methods of monitoring the condition of electrical machines," Proc. Institute of Acoustics, vol. 12, pt. 6, 1990, pp. 9-18.

[326] F.C. Trutt, "Steady state analysis of wound-rotor induction machines with simultaneous stator and/or rotor faults," Electric Machines \& Power Systems, vol. 16, n ${ }^{\circ}$, September 1989, pp. 35-48.

[327] R.C. Kryter et al., "Condition monitoring of machinery using motor current signature analysis" Sound \& Vibration, September 1989, pp., 14-21.

[328] R. Natarajan et al., "Failure identification of induction motors by sensing unbalanced stator currents," IEEE Trans. Energy Conversion, vol. 4, n² , September 1989, pp. 585-590.

[329] D.E. Schump, "Reliability testing of electric motors," IEEE Trans. Industry Applications, vol. 25, n³, May-June 1989, pp. 386-390.

[330] G.J. Paoletti et al., "Improving existing motor protection for medium voltage motors," IEEE Trans. Industry Applications, vol. 25, n³, May-June 1989, pp. 456-464

[331] V.A. Tereshnokov, "Magnetic forces in electric machines with air gap eccentricities and core ovalities," Elektrotechnika, vol. 60, n 9, 1989, pp. 50-53.

[332] F.L. Ding et al., "Calculation of frequency spectra of electromagnetic vibration for wound-rotor induction machines with winding faults," Electric Machines \& Power Systems, vol., 14, n³, 1988, pp. 137-150.

[333] T. Sobczyk et $a l$., "Analysis of current and electromagnetic torque in steady-state of induction motors with asymmetric stator windings," (in German), Arch. für Elektrotechnik, n 17, 1988, pp. 245-256. 
[334] W.T. Thomson et al., "On-line diagnostics of large induction motors," Vibrations and Audible Noise in Alternating Machines, R. Belmans et al., Eds.: Kluwer, 1988.

[335] G.B. Kliman et al., "Noninvasive detection of broken bars in operating induction motors," IEEE Trans. Energy Conversion, vol. 3, n 4 , December 1988, pp. 873-879.

[336] G.C. Stone et al., "Investigation of turn failure mechanisms in large AC motors," IEEE Trans. Power Apparatus \& Systems, vol. 103, September 1988, pp. 2588-2595.

[337] R. Natarajan et al., "Condition monitoring of slip-ring induction motors," Electric Power Systems Research, n 15 , 1988, pp. 189-195.

[338] W.T. Thomson et al., "Case histories of on-line rotor cage fault diagnosis," J. Condition Monitoring, n² 2 , 1988, pp. 25-46.

[339] O.M. Nassar, "The use of partial discharge and impulse voltage testing in the evaluation of interturn insulation failure of large motors," IEEE Trans. Energy Conversion, vol. 2, n4 , December 1987.

[340] W.T. Thomson et al., "An on-line, computer-bases current monitoring system for rotor fault diagnosis in three-phase induction motors," Turbomachinery International, November-December 1987, pp. 17-24.

[341] S. Williamson et al., "Steady state analysis of double-cage induction motors with rotor-cage faults," IEE Proc., vol. 134, pt. B, n 4 , July 1987, pp. 199-206.

[342] D.J.T. Siyambalapitiya et al., "A rotor condition monitor for squirrelcage induction machines," IEEE Trans. Industry Applications, vol. 23, n², March-April 1987, pp. 334-340.

[343] IAS Motor Reliability Working Group, "Report of large motor reliability survey of industrial and commercial installations, Part III," IEEE Trans. Industry Applications, vol. 23, n 1, January-February 1987, pp. 153-158.

[344] R.A. Leonard et al., "Vibration and stray flux monitoring for unbalanced supply and inter-turn winding fault diagnosis in induction motors," British Journal of Non-Destructive Testing, July 1986, pp. 211-215.

[345] J. Penman et al., "Condition monitoring of electrical drives," IEE Proc., vol. 133, pt. B, n³, May 1986, pp. 142-148.

[346] J.R. Cameron et $a l$., "Vibration and current monitoring for detecting airgap eccentricity in large induction motors," IEE Proc., vol. 133, pt. B, n³, May 1986, pp. 155-163.

[347] P.J. Tavner et al., "Monitoring generators and large motors," IEE Proc., vol. 133, pt. B, n³, May 1986, pp. 169-180.

[348] P.F. Albrecht et al., "Assessment of the reliability of motors in utility applications-Updated," IEEE Trans. Energy Conversion, vol. 1, n 1 , March 1986, pp. 39-46

[349] A. Wilson et al., "Discharge detection techniques for stator winding," IEE Proc., vol. 132, pt. B, n5, September 1985, pp. 234-244.

[350] IAS Motor Reliability Working Group, "Report of large motor reliability survey of industrial and commercial installations, Part II," IEEE Trans. Industry Applications, vol. 21, n², July-August 1985, pp. $865-872$.

[351] IAS Motor Reliability Working Group, "Report of large motor reliability survey of industrial and commercial installations, Part I," IEEE Trans. Industry Applications, vol. 21, n²4, July-August 1985, pp. 853-864.

[352] J.T. Renwick et $a l$., "Vibration analysis - A proven techniques as a predictive maintenance tool," IEEE Trans. Industry Applications, vol. 21, n², March-April 1985, pp. 324-332.

[353] R. Belmans et al., "Influence of torsional vibrations on lateral oscillations of induction motors rotors," IEEE Trans. Power Apparatus \& Systems, vol. 104, n7, 1985, pp. 1832-1837.

[354] S. Williamson et al., "Analysis of cage induction motors with stator winding faults," IEEE Trans. Power Apparatus \& Systems, vol. 104, $\mathrm{n}^{\circ} 7,1985$, pp. 1838-1842.

[355] I. Kerszenbaum et al., "The existence of large interbar currents in three phase squirrel cage motors with rotor-bar and/or end-ring faults," IEEE Trans. Power Apparatus \& Systems, vol. 103, July 1984, pp. 1854-1862.

[356] J.T. Renwick, "Condition monitoring of machinery using computerized vibration signature analysis," IEEE Trans. Industry Applications, vol. 20, n³, May-June 1984, pp. 519-527.
[357] W. Deleroi, "Broken bars in squirrel cage rotor of an induction motor, Part I: Description by superimposed fault currents," (in German), Arch. für Elektrotechnik, vol. 67, 1984, pp. 91-99.

[358] W.T. Thomson et al., "Failure identification of offshore induction motor systems using on-condition monitoring," Reliability Engineering, ${ }^{\circ} 9,1984$, pp. 49-64.

[359] J.E. Timperley, "Incipient fault identification through neutral RF monitoring of large rotating machines," IEEE Trans. Power Apparatus \& Systems, vol. 102, n³, March 1983.

[360] S. Williamson et al., "Steady state analysis of three-phase double cage motors with rotor-bar and end-ring faults," IEE Proc., vol. 129, pt. B, $\mathrm{n}^{\circ}$ 3, May 1982, pp. 93-100.

[361] P. Vas, "Steady-state and transient analysis of induction motors with rotor asymmetry," IEEE Trans. Power Apparatus \& Systems, vol. 101, January 1982, pp. 3246-3251.

[362] M. Ito et al., "Effect of broken rotor bars on unbalanced magnetic pull and torque of induction motors," Electrical Engineering Trans. of Japan, vol. 100, January 1980, pp. 42-49.

[363] P. Vas, "Stator asymmetries in three-phase induction motors," Elektrotechnika, vol. 71, 1978, pp. 185-192.

[364] A.J. Ellison et al., "Effects of rotor eccentricity on acoustic noise from induction machines," IEE Proc., vol. 118, pt. B, n ${ }^{\circ}$, January 1977 , pp. 174-184.

[365] P. Vas, "Investigation of squirrel-cage induction motors with concentrated type of rotor asymmetries," Elektrotechnika, vol. 68 , 1975, pp. 461-463.

\section{BIOGRAPHY}

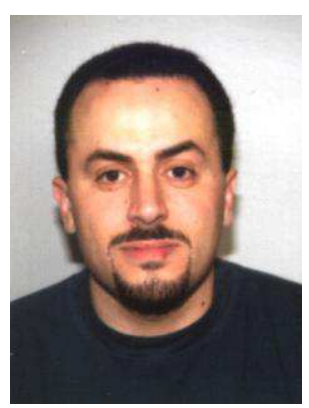

Mohamed El Hachemi BENBOUZID (S'92-M'94) was born in Batna, Algeria, in 1968. He received the B.Sc. degree in Electrical Engineering, in 1990, from the Electrical Engineering Institute of Batna University, Algeria; the M.Sc. and Ph.D. degrees both in Electrical and Computer Engineering, from the National Polytechnic Institute of Grenoble, France, in 1991 and 1994 respectively. After graduation, he joined the University of Picardie "Jules Verne", France, where he is an Associate Professor of Electrical and Computer Engineering at the Professional Institute of Amiens. His current research interests include electric machines and drives, computational of electromagnetics, and electromechanical actuation, as well as techniques for energy savings. Dr. Benbouzid is a member of the IEEE Industrial Electronics, Industry Applications, Power Engineering, and Magnetics societies, and the French Electrotechnical and Electronic Association (SEE). He is particularly active in the IEEE Power Engineering Society Working Group on Motor Maintenance and Failure Analysis of the Induction Machinery Subcommittee of the Electric Machines Committee. (phone +33 3228276 80, Fax +33 3228278 22, e-mail m.benbouzid@ieee.org) 